This item was submitted to Loughborough's Research Repository by the author.

Items in Figshare are protected by copyright, with all rights reserved, unless otherwise indicated.

\title{
Training leisure centre instructors: client motivational profiles examined
}

PLEASE CITE THE PUBLISHED VERSION

PUBLISHER

(C) Emerald

LICENCE

CC BY-NC-ND 4.0

\section{REPOSITORY RECORD}

Kniveton, Bromley H.. 2019. "Training Leisure Centre Instructors: Client Motivational Profiles Examined". figshare. https://hdl.handle.net/2134/2693. 
This item was submitted to Loughborough's Institutional Repository by the author and is made available under the following Creative Commons Licence conditions.

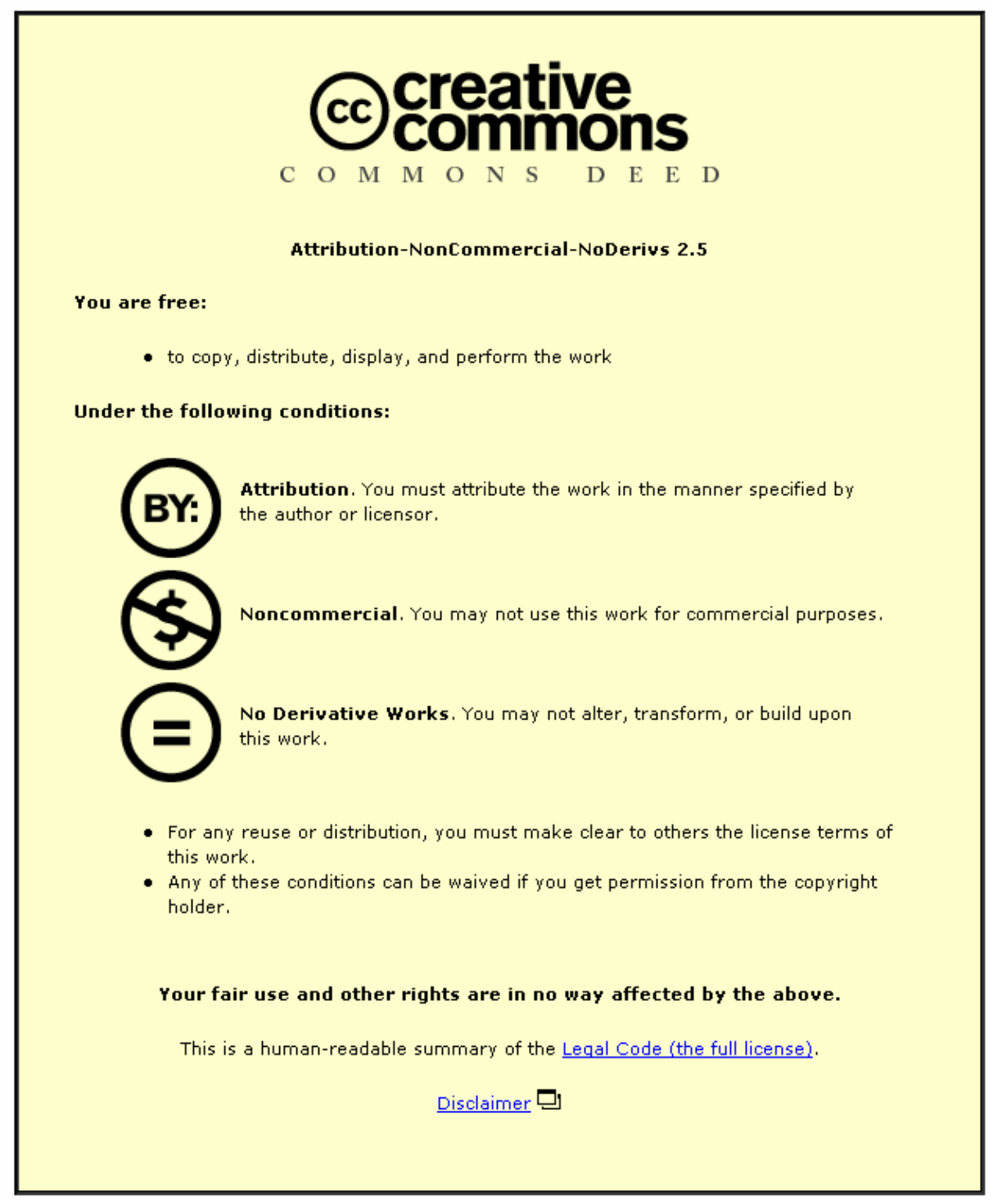

For the full text of this licence, please go to: http://creativecommons.org/licenses/by-nc-nd/2.5/ 
Journal of European Industrial Training. 29.8. 627-640 2005

\title{
TRAINING LEISURE CENTRE INSTRUCTORS: CLIENT MOTIVATIONAL PROFILES EXAMINED
}

\author{
Bromley H. Kniveton \\ Department of Social Sciences, Loughborough University, \\ Loughborough, Leicestershire. LE11 3TU
}

\begin{abstract}
Purpose: To investigate the motivations of clients attending leisure centres/clubs. It is noted training programmes for instructors tend to neglect this, particularly in relation to the gender and age of clients. Method: In this study 460 recreational athletes including equal numbers of males and females in the two age groups, 17-27 years and 37-84 were interviewed and given a short questionnaire concerning their motives for taking part in activities in leisure centres/clubs.

Findings: It was found both gender and age influenced motivations to participate and reasons for leaving.

Implications: The need for instructors to be made aware of the very different motives driving recreational athletes to attend clubs was stressed if client wastage is to be reduced.

e mail b.h.kniveton@lboro.ac.uk
\end{abstract}

Keywords: age, client, gender, instructors, leisure, motivation

Training programmes designed for instructors in the leisure industry need to address the complex issue of client motivations. This is particularly important as most people who start attending a gym, leisure centre/club stop going within a few weeks of joining. Customer turnover is a serious problem for many enterprises. There is a real need to retain membership for commercial reasons, as the pool of potential clients is relatively small. An additional problem for the leisure industry is, according to Biddle, Backhouse and Faulkner (2004), the pattern of use as most people attend no more than two or three times a week. They argue a daily activity such as a regular walk, which the individual does with enough energy to make them short of breath, will have far more beneficial effects. The twin problems of client turnover and inappropriate participation patterns have serious implications for the training of instructors. The assumption often made by instructors, and indeed by club owners/managers, and largely supported by researchers such as Yates et al (1999), is that clients are there to become fit and healthy. Much of the emphasis in the training of instructors for the activity/leisure industry therefore tends to involve the skill aspects of the activity. The assumption is that the motive to achieve health and fitness is all that needs to be taken into account. This tends to be reflected in training courses where the issue of motivation of recreational athletes attending leisure centres/clubs is neglected.

Degree programmes from 12 universities and HNC programmes from a further 17 Further Education establishments were reviewed. Syllabus outlines, brochure detail, web based materials and in 33\% of cases outline lecture notes or similar materials were examined. Within the contents of the various syllabuses the major topics covered included organisational management, skill training, links between physiology and performance, the sociological framework, marketing and financial implications. Motivation appears mainly in three parts of programmes. First in introductory courses when it tends to outline theoretical approaches such as those based on Maslow (1943) and his instinctive desires, drive reduction theory and expectancy theory. Second it is often related to peak performance following studies such as those of Williams (2001) and Butts (2001). Third it is frequently linked to marketing, often in relation to topics such as health and weight loss. The limited exposure in courses to motivation in relation to older recreational clients is probably a reflection of its low profile in text books. Roberts (2001), for example, devotes only five pages to motivation in relation to gender and age but even this is devoted to children. This is not appropriate to the clients of most leisure and fitness clubs.

The skill based aspect of instructor training dominates the programmes of the other major providers of courses, namely the YMCA Fitness Industry training programmes and Premier Fitness Instructor 
Training courses. These two provide courses at diploma level. They tend to involve topics such as training as personal trainers, fitness trainers, nutrition advisors and skill based training for individual activities such as circuit training, business skills, first aid at work and walking.

A senior manager involved with staff recruitment in each of the 19 leisure centres/clubs included in this study was interviewed by the researcher to obtain detail of staff profiles. The 10 larger clubs, $(4,000$ to 8,000 members) all attached to larger organisations, tended to average about 40 per cent graduates amongst their vocational staff. In the 9 smaller clubs (1500 to 3,999 members) the percentage of graduates falls to about $10 \%$. The smaller clubs tend to employ more 18 year olds who only held YMCA, and Premier qualifications. The larger clubs do more 'in house' training to upgrade their staff whereas the small clubs rely more on the YMCA and Premier courses. 84 per cent of the instructors employed were in the 19 to 29 year age range. The courses provided 'in house' have many titles varying with the club concerned but examples include life guard training, food hygiene, health and safety and service culture training. The latter involves training in customer skills.

During the interviews with the managers when asked 'what extra training or expertise would you like your staff to have?' in every instance the answers involved remarks such as the need for them to provide good service, and to appreciate that the customer is king. Other items mentioned were: To have older instructors because of the older age profile of clients (11 clubs). Graduates often need more skill based training and we have to send them on YMCA or Premier courses (7 clubs). For our instructors to show more drive and enthusiasm' (5 clubs). To have someone with the training to work with pregnant women' (3 clubs). Thereafter various other items were mentioned by no more than one individual manager. From an analysis of the training programmes previously described at degree, HNC, diploma and 'in house' it would appear an awareness of what the clients motives are is a neglected area.

According to Birrell and Cole (1994) two major demographic variables which divide the population are gender and age. This would certainly seem to be of relevance to leisure centre/club managers in respect of the need for staff to understand the motivation of their clients. They typically have both male and female clients of a wide range of ages. According to Coakley, (2003) sport has traditionally been a male preserve and it is only in recent years the importance of sport in relation to females has been recognised. Gill (2004) points out the major difference noted is that males tend to be more competitive athletes. These observations are however based on young competitive athletes and cannot really be applied to recreational athletes attending leisure clubs. With regard to age this is important because of the demographic change which is shifting the emphasis on importance as consumers from the young to the old. McMurdo (1999) reports older athletes have different motives than young with greater emphasis on social and health benefits rather than winning and beating others. Concern with age according to Williams (2001) concentrates rather more on physiological factors than motivation. There is an awareness of the importance of gender and age as sociological variables in the literature, but what is lacking is a link between this and the motivation of recreational athletes.

Much of the gender research into sporting participation is based on young people and therefore cannot be readily applied to adult clients who typically form the bulk of the membership of leisure clubs. West et al (2002), for example, note the low level of physical activity of young girls. Koivula (1999) suggests this is partly a reflection of the small amount of television coverage of women's sporting activities. There is evidence that physical activities generally and some specific sports are clearly gender linked. Males, for example, tend to take part in more outdoor activities and females indoor ones. Part of the explanation for this is to do with personal security. Jogging in the streets on a winters evening may not be a wise activity for females in many cities. The low level of participation by girls is a worrying trend particularly as there is evidence (Cressy 2002) which shows girls benefit by becoming more confident in their own abilities when they take part in sport in a girl supportive environment. Biddle and Wang (2003) found, with adolescent girls, high motivation and positive self perception were related to high activity levels. Weiss, Smith and Lafayette (2002) found gender differences when looking at motivations concerning sporting activity. Girls for instance rated self esteem enhancement and supportiveness higher than did boys. Alexandris and Carroll (1997) found, in a study in Greece, males felt less constrained than females about participating in sporting activities, Yates et al (1999) found females were more concerned with activity as a means of weight reduction, whereas males were more concerned with improving their self image. This applied far more to men in their twenties than to men in their forties. With females no significant differences in this context emerged in relation to age. 
It is difficult, however, to relate these studies to the motives of older people attending leisure centres/clubs.

The decline in the percentage of elderly people taking part in strenuous physical exercise is not a new phenomena. As early as 1975 the National Council on Ageing noted only a tiny 3\% of the elderly took part. The trend continues today for Hunt, Ford and Mutrie (2001) found, with increasing age, physical activity declined and the range of activity tended to narrow and concentrate on individual rather than team activities. This is important for leisure centres as the older age group are the expanding consumer market which they need to attract if they are to ensure their viability. Alexandris and Carroll (1997) found younger adults felt less constrained than older and single adults were less constrained than married adults. Heitmann (1986) showed there to be differences between age groups in motivation to take part in activities. The participants in their sample were all 40 years and above so the age range was limited. Although, for all participants, health was the main motive, lower down the ranking of motives older female participants indicated social contacts were far more important than enhancing appearance. With younger females the reverse was the case. With male participants age did not impact significantly on these factors. The present study attempts to determine whether these sort of findings can be related to the motives of leisure centre/club members.

People's motives for doing something do not necessarily relate to the proven advantages of doing it. Much research has shown that taking part in physical activity can be beneficial. Biddle, Fox and Boucher (2000) and Evenson et al (2003) present evidence of links between physical activity and not only physical and psychological health but also pro-social behaviour. The benefits of physical activities relate to all ages, for Kaplan, Newsom, McFarland and Lu (2001) have noted there are links between physical activity in later life and a whole range of other factors which are commonly associated with a healthy life style. These include being a non smoker and having a low level of psychological distress. Rosenberg (1986) in a study of the elderly found the link between membership of a sport orientated grouping and happiness was greater amongst men than women. There can, however, be disadvantages of sport participation. For example stress can be caused as a consequence of a desire to do well. Goyen and Anshel (1998) found younger athletes experienced higher levels of stress from their sporting activities than older. This was largely a result of greater and complex pressure put on them by parents, peers and coaches. It is particularly noticeable that, according to Sheldon (2004), younger athletes tend to compare with their own best times and their target times, whereas older athletes tend to compare with age mates. There is a fine line between the need for achievement being used as a motivator and it becoming a debilitating source of stress. Instructors need to be aware, not only of these well documented advantages and disadvantages, but also of the less well documented motivations of their particular clients. It is the purpose of this study to examine these.

There is a real need for instructors to be made aware of the potentially relatively small client base available to them and the importance of retaining those they have. There is not an endless pool of replacements. There are many reasons for giving up physical activities but according to Thompson, Grant and Dharmalingam (2002), in a study of 40-54 year old New Zealanders, they found no evidence of any consistent reasons. Similarly Galparoli and Laure (1999) with school children in France, found no gender difference in the reasons given on medical certificates for being unable to participate in gymnastics classes. It is not appropriate to assume findings of these studies should be accepted to indicate there is no pattern to the reasons why clients do not continue with their active membership of leisure clubs. This problem is to be examined directly in the present study.

It is the aim of this study to examine the motivations of adult recreational athletes for taking part in physical activities provided in commercial gyms and leisure centres/clubs. The sociological variables of the gender and age of club members are of particular interest in order to provide data which could be useful for instructor training.

\section{Method:}

Participants:

An opportunity sample of 460 people attending 19 leisure centres/clubs was included in the study. Gender and age were taken into account when the participants were approached. Two age groups were included in the sample. The younger group (116 male and 114 female) with an age range from 17-27 years had a mean age of 21 years. The older group (116 males and 114 females) with an age range from 37-84 years had a mean age of 50 years. The time slots for the interviews included three randomly distributed one hour periods during the day and one hour during the evening. To take account of the far 
higher membership $(8,000)$ of some clubs than others $(1500)$ and to ensure the larger ones were not over represented approximately the same number of clients from each club were interviewed and the interview slot was terminated when sufficient persons had been contacted. Those included in the sample all met the criteria for the frequency of their activities. This involved them stating they took part in strenuous physical activity at least three times a week for at least forty minutes on each occasion. This method of approaching participants was used to ensure they were actively involved with the various activities. Pirrie (2003) points out it is hard to know what people mean when asked how much physical activity they engage in. There is a tendency, according to John and Robins (1994), to self-enhance. In the case of questioning about physical activity this would involve claiming to do more than they actually did to create an impression on the interviewer. The numbers in the different age and gender subgroups varied depending on the activity. For example more females for instance took part in aerobics and gymnastics and more males with weights while younger members more played squash. The type of activity was not of interest as motivation to attend regardless of the activity was of concern. The activities they claimed to take part in included: aerobics, bicycling, dancing, exercise machines, hiking/walking, gymnastics, running, swimming and working with weights. Activities not included were sedentary ones, such as playing cards, reading or gardening, the latter because the level of activity could not readily be monitored.

The Interview Schedule:

The interview consisted of a number of specific questions concerned with motivations towards participation in activities and attendance at the leisure centre/club. These were designed to provide an opportunity for unstructured responses. These were later categorised by the researcher and then recategorised blind by an assistant, to ensure reliability. In the 9.5 per cent of cases where agreement was not achieved a majority decision was made, determined by the blind categorisation of a second assistant. In addition a Likert style rating scale and a ranking scale were adopted for two further questions. These questions were designed partly on the basis of input from focus groups consisting of six persons in each of two groups for each age category. In each case male and females were included in separate focus groups. These groups discussed the question 'why should anyone attend a leisure centre/club?'

\section{Questions:}

Who had the greatest influence in encouraging you to start your physical activity?

The unstructured answers ranged from a friend to a doctor. The complete list of responses are detailed in table I.

Why did you initially start to take an interest in your physical activity?

The unstructured answers ranged from a desire to become fit to a means of socialising. The complete list of responses are detailed in table III.

Why are you currently taking part in your physical activity?

The response was made on a likert style questionnaire based on questions taken from Kenyon's (1968) categorisation of motivations. The responses were made on a scale from one to four for a number of motivations including enjoyment, catharsis, health and fitness, meeting a physical challenge, thrills and excitement and social purposes. The domain referred to by Kenyon as catharsis, which consisted of the two concepts recreation and relaxation, was modified. In a pilot study (described later) the participants in a debriefing expressed the view that these had very different meanings. They perceived relaxation as more passive than recreation This was also noted by Mobily (1989). This possibly explains why Kenyon found catharsis to be his least reliable domain. Participants were also asked to rank order their reasons for taking part in activities. This was an attempt to circumvent the tendency to answer positively on rating scales which was noted by John and Robins (1994).

Did you stop taking part in the activity and if so why?

The range of unstructured responses are detailed in table $\mathrm{V}$.

\section{The Pilot study:}

The pilot study of the interview schedule was conducted on a sample of thirty clients and one manager attending a leisure and fitness club. which was not included in the final sample. A number of modifications were made to the proposed schedule. Extra motivational categories frequently raised by the participants in the pilot study when they were debriefed, but not included in Kenyon's domains were included. One of these was to cope better with the experience of living. This included skills involving hand eye co-ordination, lifting things etc. Others included: to improve looks, to improve self image, and to escape from other commitments and responsibilities. In addition, it was felt by the participants in the pilot study, that health and fitness were separate concepts and the opportunity was 
taken to treat them as such. Feedback from the pilot study made it clear including these extra items on the rating scales undermined the credibility of the exercise when the extra scales were added. The participants in the pilot study regarded the resulting number of scales as being too large. It was found, however, to be acceptable to use them on the ranking task.

\section{Results:}

Who had the greatest influence in encouraging you to start your physical activity?

The main statistic significant differences between the sources of encouragement for the different gender and age subgroups are shown in table I These are the PE teacher, parent, sibling and doctor. More meaningfully these can be examined in table II where they are ranked according to priority in order of importance for each of the subgroups.

\section{Table I}

Showing significant differences between sub groups on bases of age and gender for responses to the question 'Who had the greatest influence in encouraging you to start your physical activity?'. $\mathrm{N}=460$. df $3 / 456$

* significant difference at level shown.

\begin{tabular}{|l|l|c|}
\hline \multicolumn{1}{|c|}{ Person } & F & Significance \\
\hline PE teacher & 3.616 & $.013^{*}$ \\
\hline School teacher & 2.183 & .089 \\
\hline Coach & 1.535 & .205 \\
\hline Parent & 9.577 & $.000^{*}$ \\
\hline Friend & 0.345 & .793 \\
\hline Sibling & 3.533 & $.015^{*}$ \\
\hline Partner & 7.999 & .000 \\
\hline Child & 6.281 & .000 \\
\hline Doctor & 5.225 & $.001^{*}$ \\
\hline Work colleague & 1.952 & .120 \\
\hline Media & 2.004 & .113 \\
\hline Other & 1.291 & .277 \\
\hline
\end{tabular}

It can be seen in table II that the people who encouraged the athletes to take part differ markedly depending on the age and the gender of those athletes. Two things are particular noticeable from this table. First, friends are extremely important in encouraging them to take part in the activity and second doctors have little influence!

The second most likely person to encourage participation was, for the younger sample a parent, but as would be expected this was not the case for the older sample!. The older males were encouraged to take part mostly by a partner or spouse. The older females were taken by a child, who tended to be a daughter who was either a participant already, or wanted to take part herself and encouraged the mother to go with her.

\section{Table II}

Showing responses to the question 'Who had the greatest influence in encouraging you to start your physical activity?’ . Highest score most often mentioned.

\begin{tabular}{|c|c|c|c|}
\hline $\begin{array}{l}\text { Young male } \\
\mathrm{N}=116\end{array}$ & $\begin{array}{l}\text { Older male } \\
\mathrm{N}=114\end{array}$ & $\begin{array}{l}\text { Younger female } \\
\mathrm{N}=116\end{array}$ & $\begin{array}{l}\text { Older female } \\
\mathrm{N}=114\end{array}$ \\
\hline Friend .31 & Friend .27 & Friend .30 & Friend .33 \\
\hline Parent .28 & Partner .14 & Parent .24 & Child .28 \\
\hline PE teacher .10 & Parent.14 & PE teacher .15 & Partner .15 \\
\hline Coach .10 & Other .088 & Child .092 & Other .11 \\
\hline Other .09 & $\begin{array}{l}\text { Someone on media } \\
.088\end{array}$ & Media .086 & School teacher .087 \\
\hline School teacher .078 & PE teacher .078 & Coach .078 & Work .079 \\
\hline $\begin{array}{l}\text { Someone on media } \\
.034\end{array}$ & Work colleague .07 & School teacher .06 & Sibling .07 \\
\hline $\begin{array}{l}\text { Work colleague } \\
.026\end{array}$ & Doctor .07 & Partner .052 & Doctor .053 \\
\hline Sibling .000 & School teacher .044 & Other .043 & Coach .044 \\
\hline Partner .000 & Coach.044 & Sibling .034 & Parent .044 \\
\hline
\end{tabular}




\begin{tabular}{|l|l|l|l|}
\hline Child .00 & Child .026 & Work .026 & PE teacher .026 \\
\hline Doctor .000 & Sibling .018 & Doctor .00 & Media .000 \\
\hline
\end{tabular}

Why did you initially start to take an interest in your physical activity?

The main statistical differences between reasons given spontaneously for the different age and gender subgroups are shown in table III. These are to improve looks, interest in the activity and pressure from school. More meaningfully these can be examined in table IV where they are ranked according to priority in order of importance for each of the sub groups

Table III

Showing significant differences between sub groups on bases of age and gender for responses to the question 'Why did you initially start to take an interest in your physical activity?' $\mathrm{N}=460 \mathrm{df}$ 3/456 * significant difference at level shown.

\begin{tabular}{|l|r|c|}
\hline \multicolumn{1}{|c|}{ Reason } & \multicolumn{1}{c|}{ F } & Significance \\
\hline Desire to do something & .029 & .993 \\
\hline Desire to be fit & 2.260 & .081 \\
\hline Improve looks & 10.183 & $.000^{*}$ \\
\hline Interest in activity & 4.924 & $.002^{*}$ \\
\hline Pressure from school & 3.616 & $.013^{*}$ \\
\hline Pressure from family & .800 & .494 \\
\hline Pressure from other sources & 1.297 & .275 \\
\hline Other & .856 & .464 \\
\hline To socialise & 2.003 & .113 \\
\hline
\end{tabular}

With all groups, as can be seen in table IV, the main aim spontaneously offered is the desire to be fit. Thereafter there are some interesting differences. The males claim to take part because they have an interest in the activity and a desire to do something physical. With the females more important is the desire to improve their looks. Having an interest in the activity is lower on the list for both males and females. The socialising aspect is more often quoted by both males and females who are older than by their younger contemporaries.

\section{Table IV}

Showing responses to the question 'Why did you initially start to take an interest in your physical activity?' High score most often mentioned reason.

\begin{tabular}{|c|c|c|c|}
\hline $\begin{array}{l}\text { Young male } \\
\mathrm{N}=116\end{array}$ & $\begin{array}{l}\text { Older male } \\
\mathrm{N}=114\end{array}$ & $\begin{array}{l}\text { Younger female } \\
\mathrm{N}=116\end{array}$ & $\begin{array}{l}\text { Older female } \\
\mathrm{N}=114\end{array}$ \\
\hline Desire to be fit .32 & Desire to be fit .46 & Desire to be fit .34 & Desire to be fit .41 \\
\hline $\begin{array}{l}\text { Interest in activity } \\
.28\end{array}$ & Interest in activity .24 & To improve looks .20 & To improve looks .13 \\
\hline $\begin{array}{l}\text { Desire to do } \\
\text { something } .11\end{array}$ & $\begin{array}{l}\text { Desire to do } \\
\text { something } .11\end{array}$ & Interest in activity .14 & $\begin{array}{l}\text { Desire to do } \\
\text { something } .12 \\
\end{array}$ \\
\hline $\begin{array}{l}\text { Pressure from other } \\
\text { sources. } 086\end{array}$ & To socialise. 061 & $\begin{array}{l}\text { Desire to do something } \\
.11\end{array}$ & Interest in activity .11 \\
\hline $\begin{array}{l}\text { Pressure from } \\
\text { family } .078\end{array}$ & $\begin{array}{l}\text { Pressure from family } \\
.044\end{array}$ & $\begin{array}{l}\text { Pressure from other } \\
\text { sources } .082\end{array}$ & To socialise .10 \\
\hline Other .069 & $\begin{array}{l}\text { Pressure from other } \\
\text { sources } .026\end{array}$ & $\begin{array}{l}\text { Pressure from school } \\
.063\end{array}$ & $\begin{array}{l}\text { Pressure from school } \\
.088\end{array}$ \\
\hline $\begin{array}{l}\text { Pressure from } \\
\text { school .051 }\end{array}$ & Other .026 & Other .060 & $\begin{array}{l}\text { Pressure from family } \\
.053\end{array}$ \\
\hline $\begin{array}{l}\text { To improve looks } \\
.034\end{array}$ & $\begin{array}{l}\text { To improve looks } \\
.017\end{array}$ & To socialise .043 & Other .044 \\
\hline To socialise .034 & $\begin{array}{l}\text { Pressure from school } \\
.00\end{array}$ & $\begin{array}{l}\text { Pressure from family } \\
.0345\end{array}$ & $\begin{array}{l}\text { Pressure from other } \\
\text { sources } .000\end{array}$ \\
\hline
\end{tabular}

Why are you currently taking part in your activity?

The main statistical differences for the different gender and age subgroups are shown in table $\mathrm{V}$ and these are thrills and excitement, enjoying the experience, for recreational purposes, for relaxation, to meet a physical challenge and to cope better. More meaningfully these can be examined in table VI where they are ranked according to priority in order of importance for each of the sub groups 


\section{Table V}

Showing significant differences between sub groups on bases of age and gender showing satisfactions currently received as scored on the satisfaction scale of the Likert scale for taking part in their activity. $\mathrm{N}=$ df $3 / 456$

* significant difference at level shown.

\begin{tabular}{|l|l|c|}
\hline \multicolumn{1}{|c|}{ Satisfaction received } & \multicolumn{1}{|c|}{$\mathrm{F}$} & Significance \\
\hline Social purposes & .105 & .957 \\
\hline Health and fitness & 2.092 & .101 \\
\hline The thrills and excitement & 27.777 & $.000^{*}$ \\
\hline To enjoy the experience & 3.380 & $.018^{*}$ \\
\hline For recreational purposes & 3.833 & $.010^{*}$ \\
\hline For relaxation & 10.182 & $.000^{*}$ \\
\hline To meet a physical challenge & 50.883 & $.000^{*}$ \\
\hline To cope better & 9.782 & $.000^{*}$ \\
\hline
\end{tabular}

For everyone the primary motivation, as can be seen in table VI, is for health and fitness. Thereafter the motives of the younger males become rather different from the other three groups. They feel the physical challenge and thrill of the activity are important, whereas with all the other groups this is much lower on the rating. The other groups are more concerned with recreational, social purposes and relaxation.

Table VI

Showing satisfactions currently received from taking part. Highest score indicates positive ranking on the satisfaction scale of the Likert scale for taking part in their activity.

\begin{tabular}{|c|c|c|c|}
\hline $\begin{array}{l}\text { Young male } \\
\mathrm{N}=116\end{array}$ & $\begin{array}{l}\text { Older male } \\
\mathrm{N}=114\end{array}$ & $\begin{array}{l}\text { Younger female } \\
\mathrm{N}=116\end{array}$ & $\begin{array}{l}\text { Older female } \\
\mathrm{N}=114\end{array}$ \\
\hline $\begin{array}{l}\text { Health and fitness } \\
3.34\end{array}$ & $\begin{array}{l}\text { Health and fitness } \\
3.35\end{array}$ & Health and fitness 3.42 & Health and fitness 3.48 \\
\hline $\begin{array}{l}\text { To meet a physical } \\
\text { challenge } 3.28\end{array}$ & $\begin{array}{l}\text { For recreational } \\
\text { purposes } 3.20\end{array}$ & $\begin{array}{l}\text { For recreational } \\
\text { purposes } 3.01\end{array}$ & $\begin{array}{l}\text { For recreational } \\
\text { purposes } 3.28\end{array}$ \\
\hline $\begin{array}{l}\text { For recreational } \\
\text { purposes } 3.11\end{array}$ & For relaxation 3.09 & Social purposes 2.77 & For relaxation 3.01 \\
\hline $\begin{array}{l}\text { The thrills and } \\
\text { excitement } 3.05\end{array}$ & To cope better 2.85 & For relaxation 2.76 & To cope better 2.89 \\
\hline $\begin{array}{l}\text { Social purposes } \\
2.80\end{array}$ & Social purposes 2.79 & $\begin{array}{l}\text { To enjoy the } \\
\text { experience } 2.61\end{array}$ & Social purposes 2.75 \\
\hline For relaxation 2.60 & $\begin{array}{l}\text { To meet a physical } \\
\text { challenge } 2.75\end{array}$ & $\begin{array}{l}\text { To meet a physical } \\
\text { challenge2.54 }\end{array}$ & $\begin{array}{l}\text { To enjoy the } \\
\text { experience } 2.58\end{array}$ \\
\hline $\begin{array}{l}\text { To enjoy the } \\
\text { experience } 2.47\end{array}$ & $\begin{array}{l}\text { The thrills and } \\
\text { excitement } 2.45\end{array}$ & To cope better 2.52 & $\begin{array}{l}\text { To meet a physical } \\
\text { challenge } 2.13\end{array}$ \\
\hline To cope better 2.40 & $\begin{array}{l}\text { To enjoy the } \\
\text { experience } 2.30\end{array}$ & $\begin{array}{l}\text { The thrills and } \\
\text { excitement } 2.47\end{array}$ & $\begin{array}{l}\text { The thrills and } \\
\text { excitement } 2.12\end{array}$ \\
\hline
\end{tabular}

As can be seen from table VII there are statistical differences for most of the factors.

Detail of how the pattern of responses relate to the four subgroups is outlined in table VIII when the participants were forced to prioritise the options. When forced by the ranking task to consider the relative importance of factors, enjoyment which was low on the Likert scale shown in table VI is considered to be an important motive. It is interesting to note, although the participants in the pilot study felt health and fitness were different concepts, both are high on the list of motivations for many of the recreational athletes. Gender and age influence the relative importance of factors. For example the thrills and excitement offered by the activity is more important for younger males than for any other group. Three of the additional motivations: to cope, to improve looks and to improve self image, raised by the participants in the pilot study, and not included in Kenyon's original categories, appear at the bottom of the list for most groups of participants. 


\section{Table VII}

Showing significant differences between sub groups on bases of age and gender showing what the recreational athletes feel they are getting out of their activity on the basis of the ranking scale. $\mathrm{N}=\mathrm{df}$ $3 / 456$

* significant difference at level shown.

\begin{tabular}{|l|l|c|}
\hline \multicolumn{1}{|c|}{ Satisfaction received } & \multicolumn{1}{c|}{$\mathrm{F}$} & Significance \\
\hline To improve looks & 23.5833 & $.000^{*}$ \\
\hline To cope better & 34.110 & $.000^{*}$ \\
\hline Enjoyment & .700 & .553 \\
\hline Escape & 2.897 & $.035^{*}$ \\
\hline Recreation???? & 10.321 & $.000^{*}$ \\
\hline Fitness & 1.986 & .115 \\
\hline Health & 6.606 & $.000^{*}$ \\
\hline Physical challenge & 45.632 & $.000^{*}$ \\
\hline Relaxation & 29.529 & $.000^{*}$ \\
\hline Self image & 15.000 & $.000^{*}$ \\
\hline Social purposes & 1.589 & .191 \\
\hline Thrills and excitement & 30.336 & $.000^{*}$ \\
\hline
\end{tabular}

Table VIII

Showing the rank order for what recreational athletes feel they are getting out of the activity. Low score most important reason

\begin{tabular}{|l|l|l|l|}
\hline $\begin{array}{l}\text { Young male } \\
\mathbf{N = 1 1 6}\end{array}$ & $\begin{array}{l}\text { Older male } \\
\mathbf{N}=\mathbf{1 1 4}\end{array}$ & $\begin{array}{l}\text { Younger female } \\
\mathbf{N = 1 1 6}\end{array}$ & $\begin{array}{l}\text { Older female } \\
\mathbf{N}=\mathbf{1 1 4}\end{array}$ \\
\hline Fitness 2.97 & Health 3.25 & Fitness 2.68 & Health 2.82 \\
\hline Enjoyment 3.41 & Fitness 3.29 & Health 3.58 & Fitness 3.21 \\
\hline Health 4.10 & Enjoyment 3.42 & Enjoyment 3.82 & Enjoyment 3.54 \\
\hline Recreation 4.62 & Relaxation 5.21 & Social purposes 5.79 & Relaxation 5.25 \\
\hline $\begin{array}{l}\text { Physical challenge } \\
6.30\end{array}$ & $\begin{array}{l}\text { Physical challenge } \\
6.32\end{array}$ & Self image 6.60 & Social purposes 5.83 \\
\hline $\begin{array}{l}\text { Social purposes } \\
6.43\end{array}$ & Social purposes 6.45 & Physical challenge 7.07 & Cope better 6.84 \\
\hline $\begin{array}{l}\text { Thrill and } \\
\text { excitement 6.54 }\end{array}$ & Recreation 6.67 & Relaxation 7.22 & Escape 6.90 \\
\hline Self image 7.53 & Escape 7.04 & Recreation 7.28 & Self image 7.76 \\
\hline Escape 7.83 & Cope better 7.66 & Escape 7.34 & $\begin{array}{l}\text { Physical challenge } \\
7.91\end{array}$ \\
\hline Relaxation 7.88 & $\begin{array}{l}\text { Thrill and excitement } \\
8.56\end{array}$ & To improve looks 8.36 & Recreation 8.88 \\
\hline Cope better 9.76 & Self image 9.15 & $\begin{array}{l}\text { Thrill and excitement } \\
8.81\end{array}$ & $\begin{array}{l}\text { To improve looks } \\
8.93\end{array}$ \\
\hline $\begin{array}{l}\text { To improve looks } \\
10.58\end{array}$ & $\begin{array}{l}\text { To improve looks } \\
10.95\end{array}$ & Cope better 9.36 & $\begin{array}{l}\text { Thrill and excitement } \\
9.97\end{array}$ \\
\hline
\end{tabular}

Did you stop taking part in the activity and if so why?

Almost forty nine per cent. of the sample reported they had stopped taking part in the activity at some stage. As can be seen in table IX younger males are the least likely to have stopped and older females are the most likely. As can be seen in table X there are statistical differences between the subgroups in their reasons for stopping taking part in the activity.

As can be seen in table XI the reasons given are very different depending on the gender and age of the participants. What is clear is that financial considerations are low on the list. With younger males it is health, mainly injury. With older people it is time constraints and with older females, family constraints are an additional factor. Other factors mentioned include marriage, exams, being lazy, becoming bored with the activity, changing jobs or working hours. With younger females additional factors such as pregnancy, child care problems and the demands of looking after elderly parents were mentioned. 
Table IX

Showing the percentage who have at some stage stopped taking part

\begin{tabular}{|c|c|c|c|}
\hline $\begin{array}{l}\text { Young male } \\
\mathbf{N}=\mathbf{1 1 6}\end{array}$ & $\begin{array}{l}\text { Older male } \\
\mathbf{N}=\mathbf{1 1 4}\end{array}$ & $\begin{array}{l}\text { Younger female } \\
\mathbf{N}=\mathbf{1 1 6}\end{array}$ & $\begin{array}{l}\text { Older female } \\
\mathbf{N}=\mathbf{1 1 4}\end{array}$ \\
\hline $34 \%$ & $48 \%$ & $44 \%$ & $70 \%$ \\
\hline
\end{tabular}

Table X

Showing significant differences between sub groups on bases of age and gender showing the reasons for stopping taking part in the activity on the basis of the ranking scale. $\mathrm{N}=\mathrm{df}$ 3/456 * significant difference at level shown.

\begin{tabular}{|l|l|c|}
\hline \multicolumn{1}{|c|}{ Reasons for stopping } & \multicolumn{1}{|c|}{ F } & Significance \\
\hline Health & 1.016 & .385 \\
\hline Family & 30.028 & $.000^{*}$ \\
\hline No time & 3.179 & $.024^{*}$ \\
\hline Money & 1.241 & .294 \\
\hline Other & 2.621 & $.050^{*}$ \\
\hline
\end{tabular}

Table XI

Showing reasons for stopping taking part in the activity. Highest score most frequently given

\begin{tabular}{|l|l|l|l|}
\hline $\begin{array}{l}\text { Young male } \\
\mathbf{N = 1 1 6}\end{array}$ & $\begin{array}{l}\text { Older male } \\
\mathbf{N = 1 1 4}\end{array}$ & $\begin{array}{l}\text { Younger female } \\
\mathbf{N}=\mathbf{1 1 6}\end{array}$ & $\begin{array}{l}\text { Older female } \\
\mathbf{N}=\mathbf{1 1 4}\end{array}$ \\
\hline Health .16 & No time .19 & Other .17 & Family .29 \\
\hline Other .10 & Health .17 & No time .16 & No time .17 \\
\hline Family .09 & Other .08 & Health .09 & Health .16 \\
\hline Money .09 & Family .04 & Family .02 & Other .07 \\
\hline No time .06 & Money .000 & Money .000 & Money .02 \\
\hline
\end{tabular}

\section{Discussion}

Those responsible for training instructors in activity pursuits need to ensure two aspects of the job are highlighted. First instructors require a certain level of skill in the particular activity itself and need to be able to instruct clients in that skill. Second they require an awareness of the far wider responsibility to the enterprise in which they are employed. This involves retaining clients by encouraging them to continue taking part in the activities. This latter function is the one addressed in this study. For both males and females of all ages the main person who initially encouraged them to take part in the activity was a friend. This is a factor in motivation to take part in activities which does not appear to have been recognised by other researchers such as Heitman (1986) and Weiss et al (2002). The implication of this is that many participants are attending initially as a result of social pressure from someone close to them. In many cases they were actually brought along in the first instance by that friend. With older males a second major influence is a partner or spouse and with older females it is frequently a daughter. This makes the point that many new clients do not attend alone. Very often they are accompanied by someone beginning at the same time. Slightly less frequently they are accompanied by someone already participating. Instructors need to be aware of the importance of an established relationship between their clients and ensure they encourage its maintenance. Separating friends, for example, may well increase anxiety about the unknown. Encouraging friends to work together can strengthen the commitment to the activity.

The desire to be fit and healthy was the most frequently mentioned reason for initially taking part. It is important to see this motivation is satisfied. The problem is, as has already been mentioned (Biddle, Backhouse and Faulkner 2004), the typical participation pattern of three times a week is unlikely to achieve this on its own. There is therefore a need to encourage club members to help achieve their goal by undertaking physical activities on a daily basis outside the gym. Many instructors would not considered this to be part of their job. However, if the aims of fitness are to be achieved it is necessary to encourage the idea that activity carried out outside the club is an integral part of a training programme. It is rather like the dental hygienist encouraging patients to clean their teeth between visits!. If the outside activities help make the gym programme appear more successful then the health and fitness motive is more likely to be achieved. The client is then likely to see gym attendance as a success. 
Very few of us do something for a single reason. Our motives tend to be far more complex. The participants were given a number of motivational statements and they rated the importance of each. Most rated a number of factors as being relatively important. The design of the questionnaire used in this study, asking the participants to react to each of the modified list of Kenyon's motivations, ensures secondary motives are taken into account. Simply asking why they are doing something often only elicits the primary or most socially acceptable reason. It has been shown in the present study some motives have come to the fore since Kenyon's original study in 1968. Although not too widespread, improvement in looks is, for example, mentioned by some females in the present study as being an important motivator. This can probably be explained in terms of changing attitudes towards physical activities which in the `1960’s tended to be more competitively orientated.

As has been shown in this study, gender and age variables influence motivations for participation. There are marked differences in motivations between males and females. From the instructors point of view it is important to satisfy all clients and not just one group. Those training instructors need to ensure they are aware of the importance of this. For example the improvement of looks is more important to females than males. Younger males are the only group to consider thrills and excitement an important motivator. Older age groups of both sexes find the socialising aspect more important than do younger. Instructors need to be aware of the varying motivations of their clients and be able to plan programmes and set targets to satisfy the very different motivational profiles of their various clients.

It is particularly noticeable when forced to rank their motivations in priority order, enjoyment comes quite high on the list for all participants. It is something not often mentioned by other researchers, and seems fairly crucial if participants are to be encouraged to sustain their attendance at activity or leisure venues. It is an area where instructors need guidance in their training. They need to be made aware of ways of ensuring clients not only achieve something but enjoy doing it.

Why people give up something can provide a useful insight into what needs doing in order to ensure they sustain their involvement. It is a case of finding ways of helping them cope with negative influences. It appears from the results of this study the reasons for giving up vary considerably, and are again influenced by gender and age. Two things are of particular interest. One is that financial constraints appear extremely low in the list of factors. The other is that time constraints appear to figure quite prominently for all but the younger males. The time constraint is one which is extremely important when looking at client motivation because it is really an excuse used when someone sees other things as more rewarding. This does bring to the fore the need to motivate clients to retain their involvement. It means instructors need to be conscious of, and sensitive to, the motives of their clients. Their task is far more than simply providing instruction in physical skills.

\section{References:}

Alexandris, K. and Carroll, B. (1997) Demographic differences in the perception of constraints on recreational sport participation: results from a study in Greece. Leisure Studies. 16.2. 107-125

Biddle, S. Fox,, K. and Boucher,, S. (2000) Physical activity and psychological well-being. Routledge: London

Biddle, S. Backhouse, S. and Faulkner, G. (2004) Psychological consequences of physical activity: Evidence from two diverse studies. Proceedings of the British Psychological Society. 12.2 p 152.

Biddle, S.J.H. and Wang, C.K.J. (2003) Motivation and self-perception profiles and links with physical activity in adolescent girls. Journal of Adolescence: 26. 6. 687-701.

Birrell, S. and Cole, C.L. (Eds) (1994) Women sport and culture. Champaign. Ill. USA Human Kinetics

Butts, (2001) Good to the last drop! Understanding Surfer Motivations. Sociology of Sport. Online, 4.1 4.

Coakley, J. (2003) $8^{\text {th }}$ edition. Sport in Society, McGraw Hill..

Cressy, E.C. (2002) Telling stories and playing soccer: The role of adults in reconstructing gender, sport and power through interactions with young girls. Dissertation Abstracts International: Section B. The Sciences and Engineering. 62. 11-B. 5428 
Evenson, K.R. Rosamond, W.D., Cai, J. Pereira, M.A. and Ainsworth, B.E. (2003) Occupational physical activity in the atherosclerosis risk in communities study. Annals of Epidemiology. 13. 5. 351357.

Galparoli, M. and Laure, P. (1999) Gymnastics at school: functional disability for more than three months. Science and Sports. 14. 2. 101-103.

Gill, D. L. (2004) Gender and cultural diversity across the lifespan. In Weiss, M.R. (Ed) Developmental sport and exercise psychology: A lifespan perspective. Morgantown USA. Fitness Information Technology Inc.

Goyen, M.J. and Anshel, M.H. (1998) Sources of acute stress and use of coping strategies as a function of age and gender. Journal of Applied Developmental Psychology. 19. 3. 469-486

Heitmann, H.M. (1986) Motives of older adults for participating in physical activity programmes. In McPherson, B.D. (Ed). Sport and aging_Human Kinetics. Chapter 19. 199-204.

Hunt,, K. Ford, G. and Mutrie, N. (2001) Is sport for all? Exercise and physical activity patterns in early and late middle age in the west of Scotland. Health Education. 101. 4. 151-158.

John, O.P. and Robins, R.W. (1994) Accuracy and bias in self-perception: Individual differences in self-enhancement and the role of narcissism. Journal of Personality and Social Psychology. 66. 1. 206219

Kaplan, M.S. Newsom, J.T. McFarland, B.H. and Lu, L. (2001) Demographic and psychosocial correlates of physical activity in late life. American Journal of Preventive Medicine. 21. 4. 306-312

Kenyon, G.S. (1968) Six scales for assessing attitude toward physical activity. The Research Quarterley. 39.3. 566-574.

Koivula, N. (1999) Gender stereotyping in televised sport coverage. Sex Roles. 41. 7-8. 589-604.

Maslow M.H. (1943) A theory of human motivation. Psychological Review. 50. 370-396

McMurdo, M.E. T. (1999) Exercise in old age: Time to unwrap the cotton wool. British Journal of Sports Medicine. 33. 295-296

Mobily, K.E. (1989) Meanings of recreation and leisure among adolescents. Leisure Studies. 8. 11-23.

Pirrie, A. (2003) Spoilsport: on sport and attainment. Educational Research. 45.2 2181-188

Roberts, G.C. (Ed) (2001) Advances in motivation in sport and exercise Champaign. Ill. USA Human Kinetics

Rosenberg,, E. (1986) Sport voluntary association involvement and happiness among middle-aged and elderly Americans. . In McPherson, B.D. (Ed). Sport and aging_Human Kinetics. Chapter 4. 45-52.

Sheldon, J.P. (2004) Age and gender differences in the sources of self-evaluation valued by athletes. Journal of Adult Development. 11. 1. 47-53

Thompson, S.M. Grant, B.C. and Dharmalingam, A. (2002) Leisure time in midlife: what are the odds? Leisure Studies. 21. 2. 125-143.

Weiss, M.R. Smith, A.L. and and Lafayette, W. (2002) Friendship quality in youth sport: Relationship to age, gender and motivational variables. Journal of Sport and Exercise Psychology. 24.4. 420-437.

West, P. Reeder, A.I. Milne, B.J. and Poulton, R. (2002) Worlds apart: a comparison between physical activities among youth in Glasgow, Scotland and Dunedin, New Zealand. Social Science and Medicine, 54. 4. 607-619. 
Williams, J.M. (ed) (2001) Applied sport psychology: Personal growth to peak performance. Mountain View, CA. Mayfield

Yates, A. Edman, J.D., Crago,, M. Crowell, D. and Zimmerman, R. (1999) Measurement of exercise orientation in normalsubjects: gender and age differences. Personality and Individual Differences. 27. 2. 199-209

Biographical note:

Dr Bromley Kniveton is a Senior Lecturer in Social Psychology in the Department of Social Sciences at Loughborough University. He is interested in educational methodology and industrial training. He has studied teacher-pupil perspectives of the classroom and is particularly concerned with academic performance in school. He has also investigated and evaluated teaching methods in higher education. He has devised many training courses for industry, and has written two books on training negotiators based on his early research in this field. More recent material has been published in a wide range of academic journals. 